\title{
PENENTUAN WAKTU EFEKTIF SELAMA FASE LUTEAL DALAM SINKRONISASI ESTRUS MENGGUNAAN PGF2 $\alpha$ PADA KAMBING KACANG
}

\author{
Jusak Labetubun*, I. P. Siwa, Ferdenanda Reressy \\ Jurusan Peternakan Fakultas Pertanian, Universitas Pattimura \\ Jln. Ir. M. Putuhena, Kampus Poka, Ambon 97233 \\ *Email : jusak.labetubun@ faperta.unpatti.ac.id
}

\begin{abstract}
ABSTRAK
Penelitian ini bertujuan untuk mengetahui waktu efektif selama fase luteal dalam penyerentakan birahi menggunakan PGF2 $\alpha$ pada kambing Kacang. Sebanyak sembilan ekor kambing berumur sekitar 1,5 tahun yang sudah beranak satu kali, secara acak sederhana dikelompokan pada tiga perlakuan waktu penyuntikan pada fase luteal masing-masing; P1 (penyuntikan hari ke-6 setelah penyuntikan pertama) ; P2 (penyuntikan hari ke-8) ; dan P3 (penyuntikan hari ke10). Varibel yang diamati adalah waktu timbulnya etrsus (onset estrus), tanda-tanda estrus dan angka kebuntingan. Data hasil penelitian ditabulasi dan dianalisis secara statistika menggunakan rancangan acak lengkap polah searah dengan bantuan aplikasi MINITAB Versi 14. Hasil penelitian menyimpulkan bahwa faktor perlakuan berbeda sangat nyata $(\mathrm{P}<0,01)$ terhadap onset estrus. Perlakuan P3 (penyuntikan hari ke-10) lebih baik dengan onset estrus dengan rata-rata 5,31 jam, selanjutnya perlakuan P2 dengan onset estrus 26,78 jam dan perlakuan P1 dengan onset estrus 38,87 jam. Tanda-tanda birahi sama untuk semua ternak dengan angka kebuntingan $100 \%$.
\end{abstract}

Kata kunci: Fase luteal, sinkronisasi estrus, PGF2 $\alpha$, kambing Kacang

\section{DETERMINATION OF EFFECTIVE TIME DURING THE LUTEAL PHASE IN THE LUST SYNCHRONIZATION USING PGF2A ON KACANG GOAT)}

\begin{abstract}
This study aims was to determined the effective time during the luteal phase of the lust synchronization using PGF2 $\alpha$ in Kacang goats. A total of nine tiles of goats with approximately 1.5 years of age and have given birth once, were used as observational samples. The experiments used a complete randomized design with three treatments and three replications. Treatment of injection time at each luteal phase were P1 (injection of the $6^{\text {th }}$ day after the first injection), P2 ( $8^{\text {th }}$ day injection), and P3 (10 ${ }^{\text {th }}$ day injection). The observed variables were the time of the onset of estrus, signs of estrus and pregnancy rate. The data were tabulated and analyzed statistically using a randomized complete design with the help of MINITAB Version 14. The results showed that the treatment factor was significantly different effect $(\mathrm{P}<0.01)$ on onset of estrus. The onset estrus average were 5.31, 26.78, and 38.87 hours respectively for P3, P2, and P1. Signs of lust are the same for all cattle with a pregnancy rate of $100 \%$.
\end{abstract}

Key words: Luteal phase, lust synchronization, PGF2 $\alpha$, Kacang goat

\section{PENDAHULUAN}

Perkembangan di bidang teknologi reproduksi peternakan telah mengalami kemajuan yang singnifikan, baik yang berhubungan dengan rekayasa genetik maupun rekayasa di bidang hormonal dan teknik pelaksanaanya pada ternak. Dampak dari perkembangan tersebut salah satunya adalah dipersingkatnya waktu untuk melakukan perkawinan dan/atau dimodifikasikannya siklus estrus sedemikian rupa sehingga perkawinan dapat disesuaikan dengan keinginan pelaku kegiatan di bidang reproduksi peternakan.
Toelihere (1985) menyatakan bahwa untuk melakukan perkawinan pada ternak, maka peternak atau inseminator sekurang-kurangnya harus mengontrol siklus estrus minimal dalam satu periode siklus estrus, sehingga peternak dan/atau inseminator dapat menentukan waktu yang terbaik untuk melakukan perkawinan. Kondisi ini tentunya sangat merepotkan peternak atau inseminator karena waktu dan tenaga yang diperlukan sangat banyak. Tetapi dengan ditemukanya prostaglandin sebagai bahan yang dapat melisis corpus luteum (CL) maka persoalan pengontrolan estrus dengan waktu yang lama telah teratasi. 
Terdapat berbagai jenis dan cara yang telah digunakan untuk memanipulasi siklus estrus pada ternak, seperti penggunaan progesteron maupun estrogen, tetapi preparat yang paling resent adalah prostaglandin dalam bentuk prostaglandin F2 alfa (Toelihere, 1985 ; Fauzi dkk., 2017). Lebih lanjut Nalbandov (1990) menyatakan bahwa terdapat prostaglandin baik dalam bentuk E, D maupun F, sedangkan yang dinyatakan Frandson (1993) adalah terdapat empat golongan prostaglandin yaitu; A, B, E dan F, tetapi prostaglandin F2 alfa adalah yang bersifat luteolisis. Prostaglandin menurut Nalbandov (1990), adalah kelompok lipid alami yang telah diisolasi dari jaringan kebanyakan spesies, mulai dari mamalia sampai kerang.

Fungsi prostaglandin F2 alfa (PGF2 $\alpha$ ) adalah melisis corpus luteum (CL), akibatnya blok dari progesterone yang dihasilkan oleh CL terhadap hormone gonadotropin hilang, sehingga terjadi pertumbuhan dan pematangan folikel (Feradis, 2010; Hou et al., 2008 ; Toelihere, 1985). Sifat dari prostaglandin sebagai bahan yang bersifat luteolisis, juga dibuktikan oleh Labetubun (1985), dengan melakukan sebuah eksperimen menggunakan enam (6) ekor sapi Bali berumur sekitar 1,5 tahun untuk mengetahui efektifitas kerja PGF2 $\alpha$ dalam bentuk enzaprost $F$, terhadap penyerentakan birahi. Hasil yang diperoleh adalah terjadi berahi yang serentak pada sekitar 12,67 jam setelah penyuntikan prostaglandin tahap kedua di hari yang ke-12.

Hasil penelitian oleh Renda dan Dethan (2018), dengan menggunakan dosis PGF $2 \alpha 2 \mathrm{ml}, 3 \mathrm{ml}$ dan $4 \mathrm{ml}$ pada ternak babi memberikan presentasi estrus yang tidak berbeda $(P>0,05)$. Sedangkan Fauzi dkk. (2017) dalam penelitianya mengenai pengaruh pemberian prostaglandin f2 alpha terhadap waktu kemunculan birahi dan keberhasilan inseminasi buatan pada sapi Brahman Cross (Bx) Heifers memberikan hasil yang baik. Semua hasil yang telah diperoleh memperlihatkan bahwa efektifitas kerja dari hormon prostaglandin F2 $\alpha$ sangat baik karena dapat melisis CL sehingga terjadi estrus pada ternak.

Menurut Toelihere (1985), penyerentakan berahi menggunakan PGF2 $\alpha$ pada ternak efektif dapat menyebabkan berahi secara serentak sekitar 2 sampai 3 hari dan proses penyuntikan dapat dilakukan dalam 2 tahap, dengan tahap kedua dapat dilakukan pada hari ke10 sampai hari ke-12. Pendapat tersebut secara akademik tentunya sangat terkait dengan periode siklus estrus dari ternak yang akan diserentakan birahinya. Hal ini berarti bahwa periode yang dimaksud adalah fase luteal atau fase CL pada siklus birahi estrus. Persoalannya ialah bahwa fase luteal dalam satu siklus estrus berlangsung sekitar 15-16 hari (siklus estrus 21 hari). Dimana fase folikuler yang terdiri dari fase pro estrus sekitar 2-3 hari dan fase estrus sekitar rata-rata 34-38 jam sehingga fase folikuler berlangsung sekitar 56 hari (Feradis, 2010).
Waktu yang dianjurkan untuk pelaksanaan penyerentakan birahi menggunakan hormon PGF2 $\alpha$ hanya pada hari 10-12 untuk penyuntikan kedua (Toelihere, 1985). Dalam hal ini, bila diperkirakan bahwa penyuntikan pertama dilakukan tanpa diketahui pada fase estrus yang mana ternak tersebut berada maka sudah pasti di hari 10-12, ternak telah berada pada fase luteal. Hanya saja waktu tersebut dianggap terlalu lama. Sebab bila penyuntikan dilakukan pada fase folekuler katakanlah hari ke-16 dan 17 dari siklus estrus maka sudah pasti lima hari kemudian ternak sudah berada pada fase luteal. Demikian pula bila dilakukan penyuntikan secara kebetulan terjadi pada fase luteal maka sekitar 12,67 jam kemudian, ternak telah berada pada fase folikuler dan sekitar 5-6 hari kemudian ternak telah berada pada fase luteal. Hal itu berarti bahwa penyuntikan PGF2 $\alpha$ sebelum hari ke-10 dimungkinkan untuk dilakukan dengan hasil yang baik pula. Hal inilah yang menjadi dasar dilakukannya penelitian dengan judul "Penentuan Waktu Efektif Selama Fase Luteal Dalam Sinkronisasi Estrus Menggunaan PGF2 $\alpha$ Pada Kambing Kacang”. Penelitian menggunakan kambing kacang sebagai pilihan karena kambing kacang merupakan usaha peternakan lokal yang sudah adaptif dengan lingkungan setempat dan mudah didapat. Sekaligus penelitian hendak membuktikan bagaimana efek luteolitik PGF2 $\alpha$ pada ternak kambing selama fase luteal diluar hari ke-10 sampai hari ke-12 pada penyuntikan kedua.

\section{BAHAN DAN METODE}

Penelitian ini dilakukan secara eksperimental dengan menggunakan sembilan (9) ekor kambing betina berumur 1,5 tahun dan sudah beranak satu kali, serta 2 ekor kambing jantan (digunakan untuk mengontrol estrus sekaligus sebagai pemacek). Sembilan ekor kambing kacang diperoleh dari seorang peternak di desa Kairatu, Kabupaten Seram Bagian Barat secara acak sederhana dibagikan pada 3 perlakukan waktu penyuntikan PGF2a selama fase luteal masing-masing; 1) penyuntikan hari ke-6 sebagai $P 1,2)$ penyuntikan hari ke-8 sebagai $\mathrm{P} 2$, dan 3) penyuntikan hari ke-10 sebagai P3. Penyuntikan PGF2 $\alpha$ dilakukan secara intramuscular dengan dosis hormon sebanyak $1,5 \mathrm{ml}$ untuk setiap ternak pada semua perlakukan. Dimana penerapan perlakukan P1, P2 dan P3 dilakukan setelah penyuntikan tahap 1 . Penyuntikan tahap ini dilakukan tanpa observasi estrus terlebih dahulu. Tetapi semua ternak yang dijadikan hewan percobaan telah ditelusuri derajat kenormalan reproduksinya melalui data sekunder dari peternak. Demikian pula terhadap umur ternak selain diketahui melalui cacatan dari peternak, tetapi juga dilakukan pemeriksaan gigi permanen sebagai salah satu acuan. Selanjutnya dilakukan pengacakan untuk menempatkan ternak pada perlakuan yang ingin dicobakan, sehingga setiap perlakukan memperoleh masing-masing 3 ekor kambing Kacang sebagai ulangan. Dalam hal pemberian pakan, diberikan 
pakan hijauan secara ad libitum, dan setiap ternak ditempatkan pada petak berukuran 1,5 x $1 \mathrm{~m}$ dan ditampung pada satu buah kandang. Pemberian perlakukan dilakukan setelah masa adaptasi atau penyesuaian selama 1 minggu.

Variabel yang diamati adalah; 1) Waktu timbulnya estrus (onset estrus) yaitu waktu yang diperlukan oleh ternak untuk memperlihatkan tandatanda estrus setelah diberikan perlakuan ; 2) Tandatanda estrus, adalah tanda-tanda yang mengindikasi bahwa ternak telah memperlihatkan estrus dengan ciriciri; ternak tidak tenang, sering kencing, mengeluarkan suara yang khas, berdiam bila dinaiki, menaiki teman, ekor dikibaskan ke atas, vula bengkak dan merah, vulva hangat bilah diraba. Selain ciri - ciri tersebut, pejantan pun dilepaskan pada satu areal bersama betina dengan tanda-tanda yang diidetifikasi sebagai tanda-tanda estrus dan pejantan terus mendekati betina sambil mencium vulva dan ingin menaiki dan hewan betina bersedia dinaiki ; 3 ) Presentasi estrus adalah banyaknya ternak yang estrus dari seluruh ternak yang dijadikan hewan percobaan dan ; 4) Angka kebuntingan adalah banyaknya ternak yang bunting dari seluruh ternak yang telah memperlihatkan estrus dan dilakukan perkawinan dengan menggunakan pejantan.

Tabel 1. Waku Timbulnya Estrus (Onset Estrus)
Data dari hasil penelitian selanjutnya ditabulasi dan dinalisis secara statistika menggunakan Rancangan Acak Lengkap pola searah (Walpole, 1980) dalam aplikasi MINITAB Versi 14, untuk variabel onset estrus. Sedangkan variabel tanda-tanda estrus dan variabel angka kebuntingan dianalisis secara diskriptif menggunakan angka persentase (proporsi).

\section{HASIL DAN PEMBAHASAN}

\section{Waktu Timbulnya Estrus (Onset Esrus)}

Ismail (2009), menyatakan bahwa onset estrus kambing lokal yang sudah melahirkan lebih dari 1 kali yang diberi prostaglandin F2 $\alpha$ secara intramuskular adalah 91,37 jam. Sedangkan lama estrus pada induk kambing secara rata-rata hanya terjadi pada masa birahi yang berlangsung selama 12-48 Jam dan bervariasi antar individu (Ginting, 2009), dan oleh Adam dkk. (2018) bahwa akhir dari estrus pada kambing selalu diikuti dengan ovulasi.

Data hasil penelitian mengenai waktu timbulnya estrus (onset estrus) pada kambing Kacang dalam penelitian ini ditunjukkan pada Tabel 1.

\begin{tabular}{cccc}
\hline Ulangan & \multicolumn{3}{c}{ Onset Estrus (Jam) } \\
\cline { 2 - 4 } & P1 & P2 & P3 \\
\hline 1 & 38,46 & 26,20 & 5,17 \\
2 & 39,00 & 27,00 & 5,30 \\
3 & 39,15 & 27,15 & 5,45 \\
\hline Rataan & 38,87 & 26,78 & 5,31 \\
\hline
\end{tabular}

Hasil pada tabel 1, memperlihatkan bahwa semua ternak yang diberi suntikan PGF2 $\alpha$ menunjukkan onset estrus yang berbeda dalam waktu, dan setelah ditabulasi dan dianalisis secara satistika, perbedaan tersebut sangat signifikan $(\mathrm{P}<0,01)$. Perlakuan $\mathrm{P} 3$ memiliki onset estrus lebih cepat dari P2 dan P1, serta $\mathrm{P} 2$ lebih cepat dari $\mathrm{P} 1$, artinya pemberian $\mathrm{PGF} 2 \alpha$ pada hari ke-10 memberikan respos terhadap onset estrus lebih cepat yaitu rata-rata hanya 5,31 Jam. Waktu tersebut 21,47 lebih cepat jam dari P2 dan 33,56 jam lebih cepat dari P1. Sedangkan antara P2 dan P1 terdapat perbedaan waktu selama 12,09 jam.

Hasil penelitian menunjukkan bahwa baik penyuntikan pada hari ke-6, hari ke- 8 maupun hari ke10 selama fase luteal sama-sama memberikan hasil yang baik terhadap onset estrus kambing Kacang. Hasil ini memperlihatkan bahwa penyuntikan selama fase luteal sangat dimungkinkan dan tidak harus dilakukan pada hari ke-10 sampai hari ke-12 seperti dianjurkan oleh Toelihere (1985). Dengan demikian hasil penelitian ini dapat dijadikan acuan bagi inseminator dalam merancang waktu perkawinan sesuai kebutuhan yang dikehendaki. Perlakuan P1 (penyuntikan di hari ke-6) setelah penyuntikan pertama memberikan hasil yang cukup lama terhadap onset estrus (Rata-rata 38,87 jam), begitu pula dengan penyuntikan hari ke-8 (P2) memberikan hasil terhadap onset estrus rata-rata 26,78 jam. Faktor yang mungkin menjadi penyebab adalah kematangan corpus luteum. Selama siklus estrus pada ternak, puncak kematangan CL terjadi pada hari ke-10 sampai hari ke-16 ( Feradis, 2010). Pada fase ini maka perlakuan P4 juga berada pada masa puncaknya, sedangkan pada hari ke-6 sampai hari ke-9, CL masih berada pada fase pertumbuhan, demikian pula dengan perkembangan P4. Keadaan ini memperlihatkan bahwa efektifitas kerja PGF2 $\alpha$ terhadap CL secara cepat sangat terkait dengan tingkat kematangan CL, dimana semakin matang CL maka semakin efektif PGF2 $\alpha$ dalam melakukan fungsi lisisnya.

Nalbandov (1990), menyatakan bahwa pada beberapa spesies korpus mencapai ukuran 70 sampai 90 $\%$ ukuran penuh pada hari ke-3 setelah pecahnya folikel, tetapi belum mencapai pertumbuhan penuh sampai kirakira hari ke-13 dari siklus 21 hari. Sedangkan pada spesies lain kecepatan tumbuh lebih merata. Dinyatakan pula oleh Nalbandov (1990) bahwa pada domba dan sapi ukuran CL yang dicapai adalah 50 sampai $60 \%$ pada hari ke-4, dan ukuran penuh pada 
domba tercapai pada hari ke-7 sampai hari ke-9 dan pada sapi kira-kira pada hari ke-10. Secara kasar kecepatan bertambah besar CL berkorelasi positif dengan kecepatan perkembangan konsentrasi progesteron. Faktor lain yang mungkin saja turut mempengaruhi adalah bahwa pada masa puncak dari kematangan CL seiring pula dengan diproduksinya PGF2 $\alpha$ alami dari ternak sehingga kemungkinan konsentrasi PGF2 $\alpha$ semakin banyak dalam darah dan memberikan pengaruh yang lebih cepat terhadap lisisnya korpus luteum.

Tabel 2. Tanda-Tanda Estrus

\begin{tabular}{|c|c|c|}
\hline Perlakuan & Tanda-Tanda Estrus & $\begin{array}{l}\text { Presentasi } \\
\text { Estrus }(\%)\end{array}$ \\
\hline $\mathrm{P} 1$ & $\begin{array}{l}\text { Ternak gelisah, ekor dikibas kibas ke atas, sering mengembik, vulvah } \\
\text { membengkak dan memerah, vulva hangat pada saat dirabah dan keluarnya } \\
\text { lendir birahi dari vulva serta hewan betina didekati pejantan sambil mencium } \\
\text { vulva dan sampai pada hewan betina siap menerima pejantan. }\end{array}$ & 100 \\
\hline $\mathrm{P} 2$ & $\begin{array}{l}\text { Ternak gelisah, ekor dikibas kibas ke atas, sering mengembik, vulvah } \\
\text { membengkak dan memerah, vulva hangat pada saat dirabah dan keluarnya } \\
\text { lendir birahi dari vulva serta hewan betina didekati pejantan sambil mencium } \\
\text { vulva dan sampai pada hewan betina siap menerima pejantan. }\end{array}$ & 100 \\
\hline P3 & $\begin{array}{l}\text { Ternak gelisah, ekor dikibas kibas ke atas, sering mengembik, vulvah } \\
\text { membengkak dan memerah, vulva hangat pada saat dirabah dan keluarnya } \\
\text { lendir birahi dari vulva serta hewan betina didekati pejantan sambil mencium } \\
\text { vulva dan sampai pada hewan betina siap menerima pejantan. }\end{array}$ & 100 \\
\hline
\end{tabular}

\section{Tanda-Tanda Estrus}

Estrus pada ternak merupakan pertanda bahwa ternak siap untuk menerima pejantan dan/ atau siap untuk dikawinkan. Tanda-tanda estrus yang umum diperlihatkan oleh ternak disaat etrus adalah; ternak gelisah, ekor dikibas kibas ke atas, sering mengembik, vulva membengkak dan memerah, vulva hangat pada saat dirabah, ternak sering kencing, ingin menaiki atau berdiam diri bila dinaiki, keluarnya lendir birahi dari vulva. Meskipun disadari bahwa ada juga ternak yang memperlihatkan sifat-sifat birahi tenang (silent heat). Dalam penelitian ini maka tanda-tanda etrsus yang ditunjukan oleh ternak percobaan adalah seperti pada Tabel 2.

Tanda-tanda estrus sebagaimana dimaksud pada tabel 2, diperlihatkan oleh semua ternak dalam percobaan tersebut. Kondisi ini memperlihatkan bahwa proses folikulogenesis setelah terjadinya regresi korpus luteum baik pada P1, P2 dan P3 terjadi secara baik. Artinya bahwa hormon FSH dalam proses pembentukan folikel yang diiringi dengan pertambahan $\mathrm{LH}$ dan meningkatnya konsentrasi estrogen yang seimbang didalam darah telah memicu tanda-tanda estrus sebagaimana dinyatakan pada tabel 2 .

Feradis (2010) menyatakan bahwa penurunan konsentrasi progesteron yang tiba-tiba pada akhir diestrus menyebabkan timbulnya rangsangan pada hypophysa anterior ditambah dengan hilangnya blokade oleh P4 menyebabkan terjadinya pelepasan FSH, LH dan LTH. Dan dalam penelitian ini dengan diberikanya PGF2 $\alpha$ pada fase luteal telah menghilangkan blok progesteron yang dihasilkan oleh CL sehingga terjadi pertumbuhan dan pematangan folikel (Toelihere,1985).

Adanya pertumbuhan dan perkembangan folikel maka gelombang estrogen meningkat sehingga ternak dapat memperlihatkan tanda-tanda estrus (Feradis, 2010). Selanjutnya Suharyati (1999) menyatakan bahwa tanda-tanda estrus pada ternak kambing adalah vulva membengkak, memerah, basah, ternak mengibasngibaskan ekor sering mengembik dan diam pada waktu dinaiki pejantan.

Tabel 3. Angka Kebuntingan (Conception rate)

\begin{tabular}{cccc}
\hline Perlakukan & Test Pack & NRR & Angka Kebuntingan $(\%)$ \\
\hline P1 & + & - & 100 \\
P2 & + & - & 100 \\
P3 & + & - & 100 \\
\hline
\end{tabular}

\section{Angka Kebuntingan Pada Hewan Percobaan}

Angka kebuntingan (Conception rate) merupakan ukuran kesuksesan dari suatu usaha di bidang peternakan sekaligus menjadi ukuran kesuburan dan kenormalan reproduktif ternak. Berbagai cara manipulatif dalam merekayasa siklus estrus pada ternak telah dilakukan, namun yang terpenting adalah terdapat respons yang positif terhadap angka kebuntingan. Hasil peningkatan angka kebuntingan menggunakan test pack dan pengamatan non return rate (NRR) selama satu periode siklus estrus pada hari ke 21 - 24 dalam penelitian ini seperti ditunjukan pada tabel 3 . 
Hasil pada tabel 3, memperlihatkan bahwa semua ternak percobaan yang mengalami estrus dan dikawinkan selanjutnya dilakukan test peck maupun menggunakan indikator NRR pada hari ke-21 sampai 24 memperlihatkan angka kebuntingan $100 \%$. Hal ini berarti bahwa PGF2 $\alpha$ memberi dampak yang positif selama fase luteal, baik pada P1, P2 maupun P3. Artinya estrus yang terjadi setelah regresi CL akibat pemberian PGF2 $\alpha$ baik pada hari ke-6, hari ke-8 maupun hari ke-10 selama fase luteal terjadi oleh karena sebuah proses folikulogenesis dan oogenesis secara baik yang diikuti dengan ovulasi sehingga pada saat dilakukan perkawinan secara tepat dengan pejantan yang baik pula, telah menghasilkan angka konsepsi yang baik pada semua perlakuan.

Salisbury dan Vandemark (1985), menyatakan bahwa hewan betina mampu menghasilkan anak hanya apabila dikawinkan dengan seekor hewan jantan yang menghasilkan spermatozoa yang selanjutnya dapat membuahi ovum dan memenuhi proses-proses yang memenuhi konsepsi, implantasi dan deferensiasi normal dari embrio dan pertumbuhan janin. Sedangkan Partodihardjo (1980), menyatakan bahwa terdapat 5 jenis kelenjar hormon yang terlibat dalam kebuntingan yaitu CL, plasenta, folikel, hipothalamus dan hipofisa tetapi yang sangat berperanan adalah CL. Dalam hal ini CL merupakan penghasil progesteron yang menandakan bahwa ternak berada dalam keadaan bunting. Indikator test peck terkait erat dengan kadar progesteron di dalam darah ternak percobaan dan hasil yang diperoleh memperlihatkan bahwa semua ternak percobaan yang mengalami estrus dan dilakukan perkawinan mimiliki angka kebuntingan $100 \%$.

\section{SIMPULAN DAN REKOMENDASI}

Berdasarkan hasil penelitian dan pembahasannya maka disimpulkan bahwa faktor perlakuan berbeda sangat nyata $(\mathrm{P}<0,01)$ terhadap onset estrus. Dimana penyuntikan selama fase luteal, baik pada hari ke-6, hari ke-8 maupun pada hari ke-10, sama-sama memberikan renspos sangat nyata terhadap timbulnya estrus. Perlakuan P3 (penyuntikan hari ke10) lebih baik dengan onset estrus rata-rata 5,31 jam, perlakuan P2 dengan onset estrus 26,78 jam dan perlakuan P1 dengan onset estrus 38,87 jam. Tandatanda birahi sama untuk semua ternak dengan angka kebuntingan $100 \%$.

Dalan program inseminasi buatan pada ternak kambing, maka kegiatan penyerentakan birahi menggunakan PGF2 $\alpha$ dapat dilakukan oleh insemintor selama fase luteal baik di hari ke-10 maupun hari ke-8 dan hari ke-6 sebagai pilihan sesuai kebutuhan inseminator.

\section{DAFTAR PUSTAKA}

Adam, M., R. N. Huda, W. Zahara, T. N. Siregar, S. Wahyuni, C. N. Thasmi, dan Rosmaidar.
2018. Perbandingan Kinerja Berahi dan Level Estradiol Kambing Kacang dan Kambing Nubian yang Diinduksi dengan PGF2 $\alpha$. Jurnal Sain Veteriner. 36(1): 3239. https://doi.org/10.22146/jsv.38444.

Fauzi, M. R., Suyadi, dan T. Susilawati. 2017. Pengaruh Pemberian Prostaglandin F2 Alpha Terhadap Waktu Kemunculan Birahi dan Keberhasilan Inseminasi Buatan Sapi Brahman Cross (Bx) Heifers. Jurnal Ilmu-Ilmu Peternakan. 27(3): 39-43.

Feradis, 2010. Bioteknologi Reproduksi Pada Ternak. Cetakan Kesatu. Hal. 115-119. Bandung: Penerbit Alfabeta.

Frandson, R. D. 1993. Anatomi dan Fisiologi Ternak. Edisi keempat. Yogyakarta: Gajah Mada University Press.

Ginting, S.P. 2009. Mengenal Birahi Pada Induk Kambing. http://blitar.blogspot.co.id.id/p/ mengenal- birahi-pada-induk-kambing.html. [04/03/2020].

Hou, X., E.. W. Arvisais, C. Jiang, D. Chen, S. K. Roy, J. L. Pate, T. R. Hansen, B. R. Rueda, and J. S. Davis. 2008. Prostaglandin F2 alpha stimulates the expression and secretion of transforming growth factor B1 via induction of the early growth response 1 gene (EGR1) in the bovine corpus luteum. Molecular Endocrinology. 22(2): 403-414.

Ismail, M. 2009. Onset Dan Intensitas Estrus Kambing Pada Umur Yang Berbeda. J. Agroland. 16 (2): 180-186.

Labetubun, J. 1987. Penyerentakan Birahi Pada Sapi Bali. [Skripsi]. Ambon: Jurusan Peternakan Fakultas Pertanian Universitas Pattimura.

Nalbandov, A.V. 1990. Fisiologi Reproduksi Pada Mamalia Dan Unggas. Edisi Ketiga. Hal. 235. Jakarta: Penerbit Universitas Indonesia, UI-Press.

Partodihardjo, S. 1980. Ilmu Reproduksi Hewan. Hal. 241. Jakarta: PT Mutiara Sumber Widya.

Renda, S. B., dan A. A. Dethan. Pengaruh Level Dosis Prostaglandin (PGF2a) pada Ternak Babi Peranakan yang Diinseminasi Buatan terhadap Persentase Estrus, Persentase Kebuntingan, Litter Size dan Berat Lahir. Journal of Animal Science (JAS). 3(3): 3234. DOI: 10.32938/ja.v3i3.427.

Salisbury, G. W., dan N. L. Vandemark. 1985. Fisiologi Reproduksi dan Inseminasi Buatan Pada Sapi. Hal 645. Yogyakarta: Gajah Mada University Press. 
Suharyati, S. 1999. Pengaruh Pemberian PMSG dan HCG Terhadap Kinerja Reproduksi Kambing Etawah Yang Disinkronisas Estrus Dengan Progesteron. [Tesis]. Yogyakarta: Program Pasca Sarjana Universitas Gadjah Mada.
Toelihere, M. R. 1985. Fisiologi Reproduksi Pada Ternak. Hal. 187-192. Bandung: Penerbit Angkasa.

Walpole, R. E. 1988. Pengantar Statistika. Edisi Ke-3. Hal. 383. Jakarta: Penerbit P.T. Gramedia.

Available online at journal homepage: http://ojs3.unpatti.ac.id/index.php/agrinimal 